\title{
GEOLOGICAL AND GEOMORPHOLOGIC CONDITIONS AND TRACES OF PREHISTORIC AND HISTORIC HUMAN SETTLEMENTS IN THE VICINITY OF ULÓW (ROZTOCZE REGION, SOUTHEASTERN POLAND)
}

\author{
Jan Rodzik ${ }^{*}$, Barbara Niezabitowska-Wiśniewska², Jerzy Nitychoruk ${ }^{3}$, \\ Janusz Budziszewski ${ }^{4}$, Michał Jakubczak ${ }^{5}$ \\ ${ }^{1}$ Faculty of Earth Sciences and Spatial Management, Maria Curie-Skłodowska University, al. Kraśnicka 2d, 20-718 Lublin, \\ Poland,jan.rodzik@poczta.umcs.lublin.pl \\ ${ }^{2}$ Institute of Archaeology, Maria Curie-Skłodowska University, Plac Marii Curie-Skłodowskiej 4, 20-310 Lublin, Poland, \\ barbara.niezabitowska-wisniewska@poczta.umcs.lublin.pl; baica@poczta.onet.pl \\ ${ }^{3}$ Pope John Paul II State School of Higher Education, ul. Sidorska 95/97, 21-500 Biała Podlaska, Poland, \\ jerzy.nitychoruk@pswbp.pl \\ ${ }^{4}$ Cardinal Stefan Wyszynski University, Institute of Archaeology, ul. Wóycickiego 1/3, 01-938 Warsaw, Poland, \\ budziszewski.janusz@gmail.com \\ ${ }^{5}$ Institute of Archeology and Ethnology, Polish Academy of Sciences, Al. Solidarności 105, 00-140 Warsaw, Poland, \\ michal.jakubczak87@gmail.com \\ * corresponding author
}

\begin{abstract}
The paper presents determinants of location of the multicultural complex of archaeological sites in the vicinity of Ulów, in the Central Roztocze upland region in south-eastern Poland. Archaeological research revealed that in the area assumed to be devoid of settlements, the settlements of prehistoric and historical communities functioned from the Palaeolithic to modern times. The region was also subjected to environmental examination. Location of sites was analysed, taking into account a convenience of communication in a regional scale and local environmental conditions. Analysis of hydrogeological, geomorphological and soil conditions was carried out, taking into account water supply, communication and the farming development. In-depth analysis included micromorphological DTM (Digital Terrain Model) and geological and soil probing. The area was found to be located on the crossing of prehistoric communication routes the course of which depended on the variability of the physiographic parameters of regions. The functioning of new cultures in the same place resulted from specific local conditions such as: easily arable soils, favourable microclimate, and particularly access to water. The presence of a source of water in a plateau area is determined tectonically (strike-slip fault), lithologically (impermeable marl horizon), and geomorphologically (dissection of the aquifer by an erosion-denudation valley).
\end{abstract}

Key words: Multicultural prehistoric settlement, traces of ancient agriculture, geology and geomorphology of Roztocze

Manuscript received 20 June 2017, accepted 28 November 2017

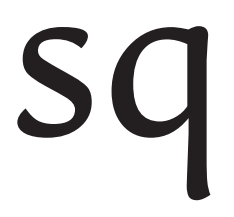

\section{INTRODUCTION}

Archaeological investigation enables to indicate preferences for settlement locations in individual prehistoric and historical periods. While choosing settlement sites, individual archaeological cultures were guided by different needs, often dependent on cyclic climate changes. However, there are areas where people of different, successive cultures settled the land permanently, e.g. in the vicinity of Ulów. This village is located in the Lublin region of south-eastern Poland. As a result of archaeological investigation, evidence of the activity of different cultures in different periods in a small area was found.

A complex of archaeological sites in the forest near Ulów was discovered by prospectors looking for arms from the Second World War. The first archaeological ex- 
ploratory works were conducted there in November 2001 and extensive excavation works have been conducted constantly since 2002. Thanks to them, it was possible to identify seven out of eight archaeological sites, which were outlined based on preliminary information given by collectors and prospectors, supplemented with field surveys conducted with their participation. Subsequent sites were discovered and about 30 barrows were located. Ten of them were excavated or explored (Bagińska and Niezabitowska, 2003, 2004; Niezabitowska, 2005, 2007, Niezabitowska-Wiśniewska, 2007, 2008, 2009, 2014a, b, 2015; Niezabitowska-Wiśniewska and Wiśniewski, 2011, in print). In 2014 the project entitled 'Roztocze - the ancient terra incognita? (Settlement micro-region in the area of Ulów in Middle Roztocze in the prehistory and its background. Interdisciplinary studies)', funded by the National Science Centre in Poland, was started. The principal aim of research is a reconstruction of prehistoric settlement processes in this area. As part of the project, archaeological, anthropological, palaeobotanical and geophysical analyses and radiocarbon dating were conducted, together with complex environmental and palaeoenvironmental research, the results thereof are presented in this paper.

Before archaeological examination in Ulów started, it was generally accepted that the area of Roztocze had been inconvenient for prehistoric settlements, the main reasons being a lack of surface waters, limited access to groundwater and topography. The assumed lack of settlements in Roztocze, particularly in the Roman period and during the migration period $\left(1^{\text {st }}-5^{\text {th }}\right.$ centuries AD) is presented on maps of settlement distribution in this time (Godłowski, 1984; Kunisz, 1985; Kokowski, 1988a, b, 1991). It concerns particularly the central part of Roztocze. Modern afforestation of the area, which makes it difficult to conduct surface analysis as part of the Archaeological Picture of Poland (Jaskanis, 1996; Kozioł et al., 2012) resulted in identification of a small number of archaeological sites. The scope of excavation works was limited, they were conducted mainly in the better known and easily accessible edges of the region (Machnik, 1959, 1960, 1961, 1966; Machnik and Potocki, 1959a, b; Rogozińska and Potocki, 1959; Potocki, 1960; Rogozińska, 1963; Balcer et al., 2002; Piotrowski, 2004, 2008).

The resulting discovery of a multicultural complex of sites in the vicinity of Ulów comprised a small area and was combined with a lack of remains of prehistoric settlements outside this complex. It raised the question why people of nearly every archaeological culture known from the Polish territory had chosen this area for their settlements. It was assumed that this was due to favourable natural conditions, including water supply and opportunity to organise a settlement dependent on subsistence model (e.g. quality of soils and their cultivation in case of farming cultures). Both the occurrence of water and types of soils are conditioned by geological structure and topography. Thus, the aim of this paper is to determine the natural conditions in the vicinity of the settlement complex at Ulów, based on geomorphological and geological analyses, and to answer the question how much they could affect development of settlement in this microregion.

Environmental determinants of prehistoric settlement location in the Polish territory has focused increasing attention of scientists from different fields of science in the recent years. It is most clearly reflected in papers published in the series of the Polish Association for Environmental Archeology entitled 'Environmental - Man - Civilization' (Makohonienko et al., 2007a; Domańska et al., 2009; Karczewski et al., 2014) or in papers devoted to geoarcheology and environmental archaeology (Makohonienko et al., 2007b; Welc and Woronko, 2011). Most frequently, previous studies were limited to a single or a few prehistorical periods or cultures (Nowaczyk, 2008; Kittel and Skowron, 2009; Karczewski 2011; Kalicki and Czerniak, 2014; Morawska, 2014; Rodzik et al., 2014; Twardy, 2014; Mroczek, and Rodzik, 2015; Rodzik and Mroczek, 2015). The main objective was to reconstruct the environmental changes in an archaeological and its surroundings, taking into account a human activity record (Klimek and Zygmunt, 2007; Zgłobicki, 2008; Szwarczewski et al., 2014; Zgłobicki et al., 2014). Geomorphological and geological studies have also become standard and complement the archaeological research prior to major investments, including highway construction (Gębica 2002a, b; Sadowski and Włodarski, 2007, 2009). A vast majority of these works focused on description of natural conditions, including geomorphology and geology in archaeological sites, but not regarding reasons of their location.

\section{MATERIALS AND METHODS}

\section{Study area - environmental conditions}

The multicultural settlement complex, located to the east of Ulów, is located in the centre of Central Roztocze (Tomaszów Roztocze). This mesoregion comprises a central section of the Roztocze macroregion, which is an arched hill, 14-28 km wide and running from NW to SE at distance of $180 \mathrm{~km}$ (Fig. 1). It is enclosed by tectonic edges to $100 \mathrm{~m}$ high (Maruszczak, 1972; Buraczyński, 2002). It connects the meta-Carpathian provinces of the Polish Uplands in the nort-west with the Ukrainian uplands in the south-east. In the direction from outh-west to northeast, it separates the North Sub-Carpathian Basin from the mesoregional basins within the meta-Carpathian uplands (Maruszczak and Sirenko, 1989/90). A considerable section of Roztocze is boundary between the main European landscape areas of western and eastern Europe (Kondracki, 2009). The Polish-Ukrainian border cuts the region, leaving a larger part of Roztocze on the Polish side.

A height of the plateau reaching $100 \mathrm{~m}$ results in diversified climate, an influence which is particularly noticeable in the Tomaszów Roztocze. A vicinity of Tomaszów Lubelski, where the annual average temperature is $7^{\circ} \mathrm{C}$, is the coldest part of the Lublin region. Here, a period of permanent snow cover is the longest (over 80 days), 


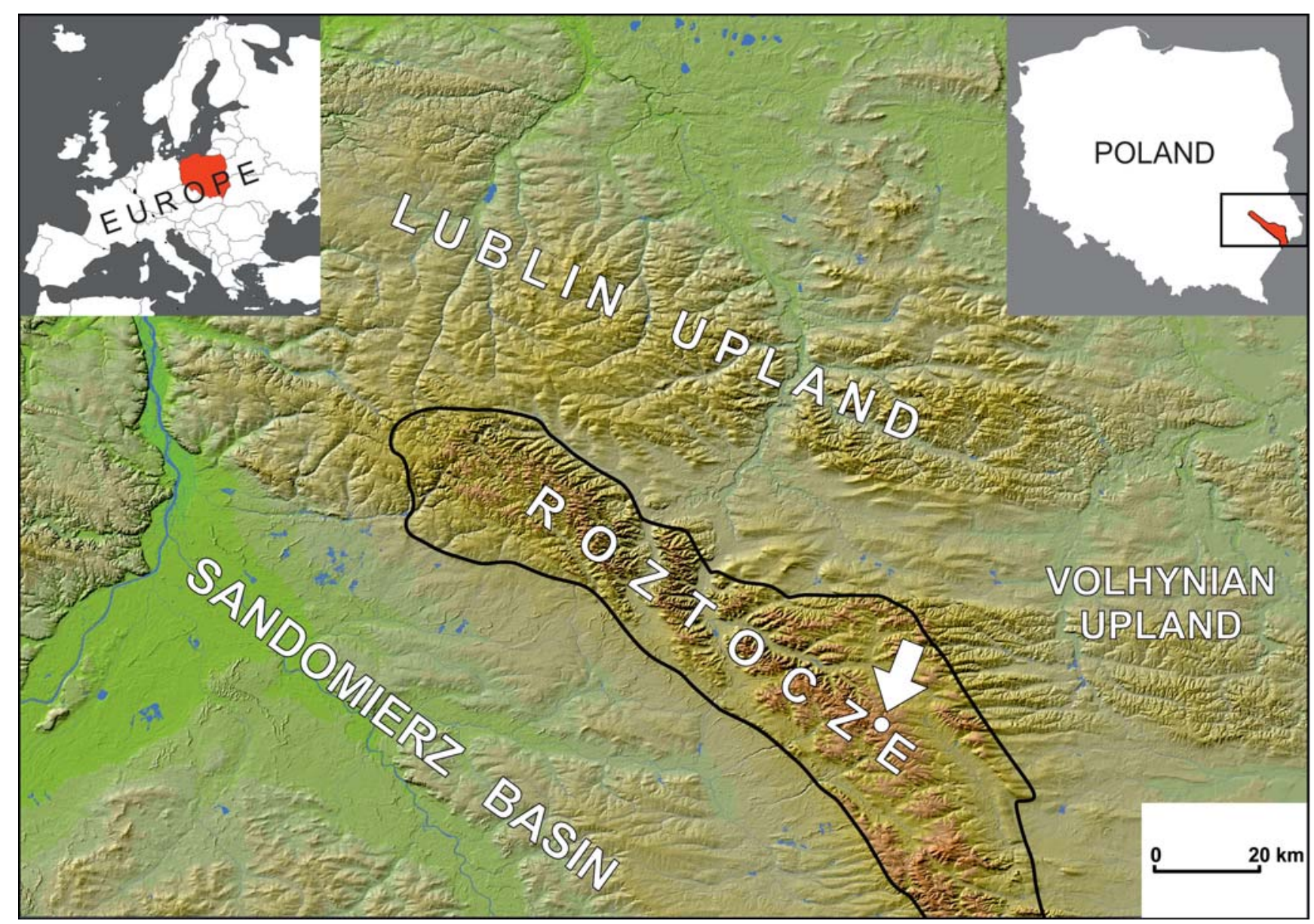

Fig. 1. Location of Ulów (shown by the arrow) at the background of the DEM model (Gawrysiak, 2004).

while the vegetation period is the shortest (about 210 days). The highest annual precipitation $(>700 \mathrm{~mm})$ is at the south-western edge of the Tomaszów Roztocze, while it is $100 \mathrm{~mm}$ lower in the north-eastern part of the mesoregion (Kaszewski, 2008). Similarly, the river outflow is diverse. In the south-western zone of the edge it exceeds $220 \mathrm{~mm}$, whereas on the opposite side it is $100 \mathrm{~mm}$ lower. Generally, the whole Roztocze acts as an important watershed and a distinct hydrographic region, with a narrow waterway network and dry watershed areas. This results from a high permeability of cover formations and substratum rocks (Michalczyk and Wilgat, 2008).

The ridge of the Roztocze consists of silicate-carbonate marine deposits of the Upper Cretaceous (mostly gaizes), which are dissected by a net of fractures and faults of NW-SE, NE-SW and N-S orientation. Valleys developed on them divide the Roztocze into isolated blocks (Brzezińska-Wójcik, 2013). One of them is the Ulów block, which includes an anticline, in the limb of which the research area is located (Fig. 2). Silicate-carbonate rocks of the Lower Maastrichtian occur in its northern part and the Upper Maastrichtian ones in its southern part (Buraczyński et al., 2002). The former are indicated by diverse, yet relatively high compressive strength levels $(8.2-39.0 \mathrm{MPa})$. The second type of rocks are characterised by lower compressive strength levels (6.0-10.0 MPa) that result from lower silica and higher carbonate content (Wyrwicka, 1977a, b). Both types of rocks do not contain any flint (Maruszczak, 1998, 2002).

The main topographical characteristics developed in the Pliocene and the Early Pleistocene, when tectonic and denudation processes took place (Jahn, 1956; Buraczyński, 2002; Brzezińska-Wójcik, 2013). A topography is predominated by a higher planation surface, which truncates the Upper Cretaceous rocks at 340-350 m a.s.l. (Fig. 3). They are cut by dry or slightly dry Pleistocene valleys, the floors of which lie at 305-320 m a.s.l. (Buraczyński and Chabudziński, 2014). A system of such valleys cuts the south-western part of the research area, where there are silicate-carbonate rocks in the substratum. The valleys developed on fractures and faults, which are indicated by their directions and asymmetry of hillsides (Buraczyński, 2002; Brzezińska-Wójcik, 2013). Pleistocene sands and clays occur at the valley floors (Buraczyński et al., 2002) and Holocene peaty silt in the boggy areas (Harasimiuk et al., 2008). The north-eastern part of the area, where the substrate is composed of resistant silicate-carbonate rocks, is slightly dissected by the valleys. This relatively flat surface extends in both the WNW and ESE directions (Buraczyński, 2013). It is cut by a partially damp small valley with a water leak in its upper part. The valley is located 


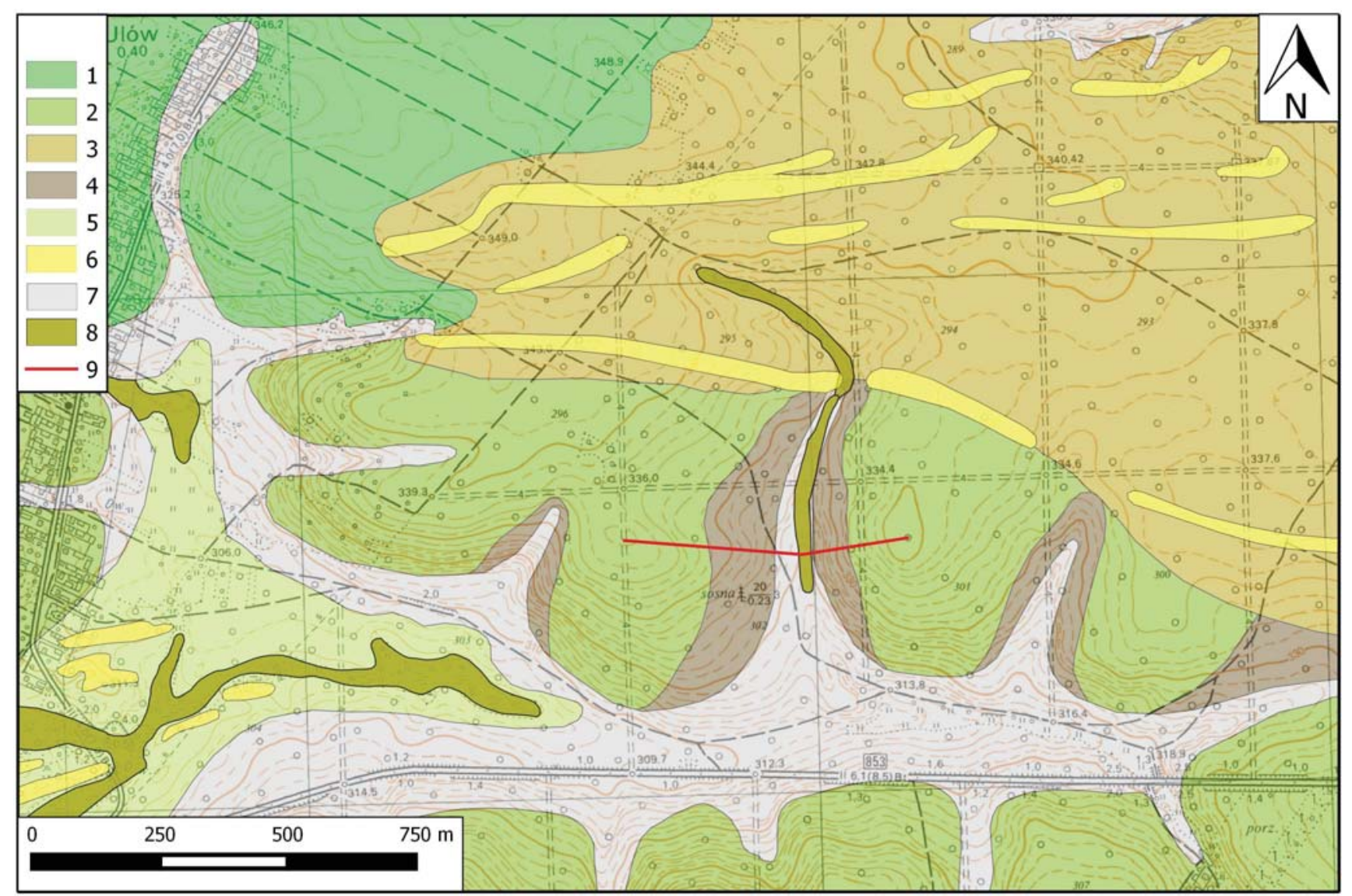

Fig. 2. Geological sketch of the Ulów area (based on Buraczyński et al., 2002, highly modified). Maastrichtian: 1 - silicate-carbonate rocks; 2 - marly silicate-carbonate rocks; Weichselian Glaciation: 3 - aeolian sand on clay and bedrock, 4 - slope sand on clay, 5 - fluvio-periglacial sand; Late Glacial: 6 - aeolian sand in dunes, 7 - colluvial sandy clay; Holocene: 8 - peaty mud; 9 - cross-section in Fig. 6.

in the centre of the research area and plays a significant role in the examined settlement centre.

\section{Distribution of archaeological sites}

Artefacts were discovered during excavations and field works in the vicinity of Ulów, outside the present built-up area. They were dated at the Late Palaeolithic to the $17^{\text {th }}$ century AD (Fig. 4). Traces of Palaeolithic and Mesolithic settlements are scarce. Their remains were discovered at a single site only, near the water leak (Wiśniewski, 2007). They included flint tools and most probably remains of two severely damaged archaeological features. ${ }^{14} \mathrm{C}$ calibrated (68.2\% of probability) dates (9118-8746 BC /Poz-76346/ to 6562-6407 BC /MKL-2728/), confirmed the settlement age (Fig. 5A). Calibrated radiocarbon ages (cal $\mathrm{AD} / \mathrm{BC}$ ) were obtained based on the IntCal13 radiocarbon calibration dataset (Reimer et al., 2013) and the OxCal 4.2 calibration software (Bronk Ramsey, 2009).

Considerably more artefacts come from the Neolithic (Fig. 5A). Traces of the Lublin-Volhynian Funnel Beaker and Corded Ware cultures are the most frequent. The settlement remains of these two cultures are spread over almost the entire research area, and the majority are concentrated near the constant water leak. All examined barrows are connected with the Corded Ware Culture. In total, the research area had at least 29 barrows forming four distinct clusters. Two of them, with three and 11 mounds, are almost completely levelled, and they are located on the hilltop. So far, seven of them have been explored (NiezabitowskaWiśniewska and Wiśniewski, 2011, in print). Radiocarbon dating provided calibrated (68.2\% of probability) dates of 3308-2941 BC (Poz-73127) to 2569-2467 BC (MKL-2846). Another cluster with nine barrows is located to the southeast of these above-mentioned one (also on a hilltop). Two barrows were excavated there. The location of the last cluster with six earthworks, diverges significantly from the others. Barrows, including one that has been excavated, are located on a sandy terrace at the valley floor (Figs 4; 5A).

Remains of a settlement from the Bronze Age were also discovered in the vicinity of Ulów (Fig. 5B). They are the traces of Mierzanowice, Trzciniec and Lusatian cultures. The fragments of ceramics of the Mierzanowice Culture were discovered in the mounds of barrows of the Corded Ware Culture or just next to them. Traces of a settlement of the Trzciniec Culture are spread over the entire research area, both on a hilltop and in a valley floor. They include a grave, settlement structures and portable ceramics in the mound of one of the barrows of the Corded Ware Culture 


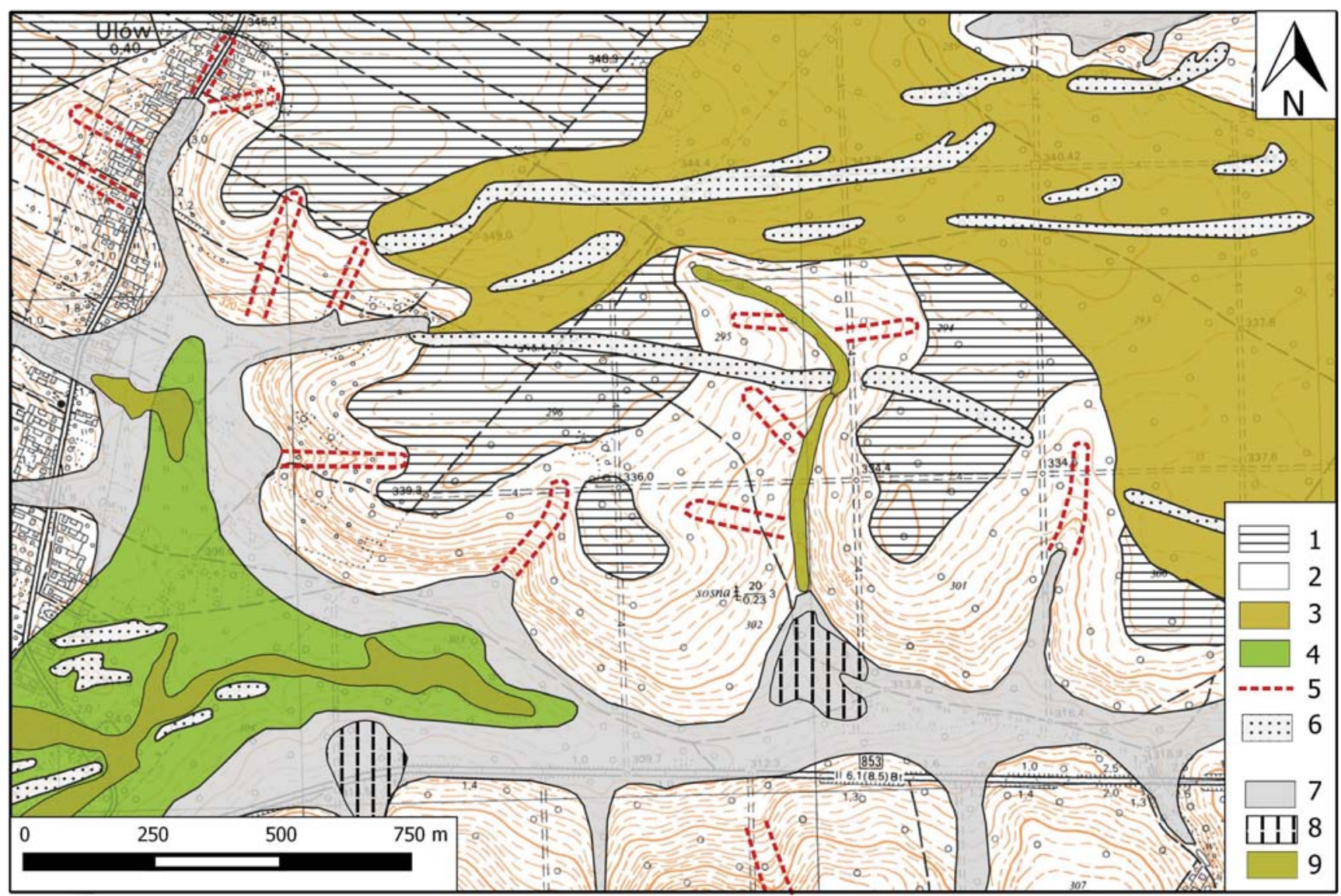

Fig. 3. Geomorphological sketch of the Ulów area (after Buraczyński, Chabudziński, 2014, modified). Pliocene: 1 - planation surface 340-360 m a.s.1.; Pleistocene: 2 - slope, 3 - aeolian plain, 4 - flood plain, 5 - trough-like valley; Late Glacial: 6 - dune, 7 - washing accumulation plain, 8 - alluvial cones; Holocene: 9 - peaty-muddy plain.

(Niezabitowska-Wiśniewska, 2014a). The traces of the settlement of the Lusatian Culture occur only on a hilltop, near the valley with a water leak.

As regards the late Roman Period and the early stage of the Migration Period (from the middle of the $3^{\text {rd }}$ century to the first half of the $5^{\text {th }}$ century AD), two settlements and two bi-ritual cemeteries of the Wielbark Culture were discovered. They are located on a hilltop and the settlements are separated from cemeteries by the valley with a water leak (Fig. 5C). Cemeteries are located to the north and east and settlements to the south and west (Niezabitowska-Wiśniewska, 2007, 2008, 2009, 2014b, 2015). Archaeological dates were confirmed by ${ }^{14} \mathrm{C}$ calibrated (68.2\% of probability) dates from 86-235 AD (MKL$2726)$ to $335-400 \mathrm{AD}$ (Poz-76349). Rare artefacts found on hilltops come from the Middle Ages (Fig. 5D), confirmed by calibrated (68.2\% of probability) dates of around 1315 1414 AD (MKL-2725).

Archaeological sources include remains of a modern settlement from the $17^{\text {th }}$ century (Fig. 5D). Near the valley with a water leak, a fragment of a large and deep structure was found, as well as stone foundations of a building from this time.

All discovered archaeological sites are located in an area of about $2.07 \mathrm{~km}^{2}$. Outside this cluster, within a
2-5 $\mathrm{km}$ radius, there are no traces of prehistoric settlements or they are limited to single artefacts, mainly fragments of ceramics.

\section{Methods}

Geological structure and topography provided based on the Tomaszów Lubelski sheet of the Detailed Geological Map of Poland in scale 1:50 000 (Buraczyński et al., 2002) were verified. So far, detailed exploration of sediments in the vicinity of Ulów has been conducted only in the valley floors (Harasimiuk et al., 2008). The principal aim of geological and soil probing was to verify a scope of surface formations and their thickness, and to determine types of soils that developed on them. They were also used to identify the structure of small, anthropogenic landforms (barrows). About 150 geological and soil borings were conducted to 1-3 m depth with a use of the manual Eijkelkamp drilling kit with a probe to collect a core with undisturbed structure. Sedimentary layers and soil horizons were identified. Type and intensity of anthropogenic transformations of the topographic surface was determined, employing the pedological method described by Rodzik and Mroczek (2015). This method was successfully used to determine changes, 


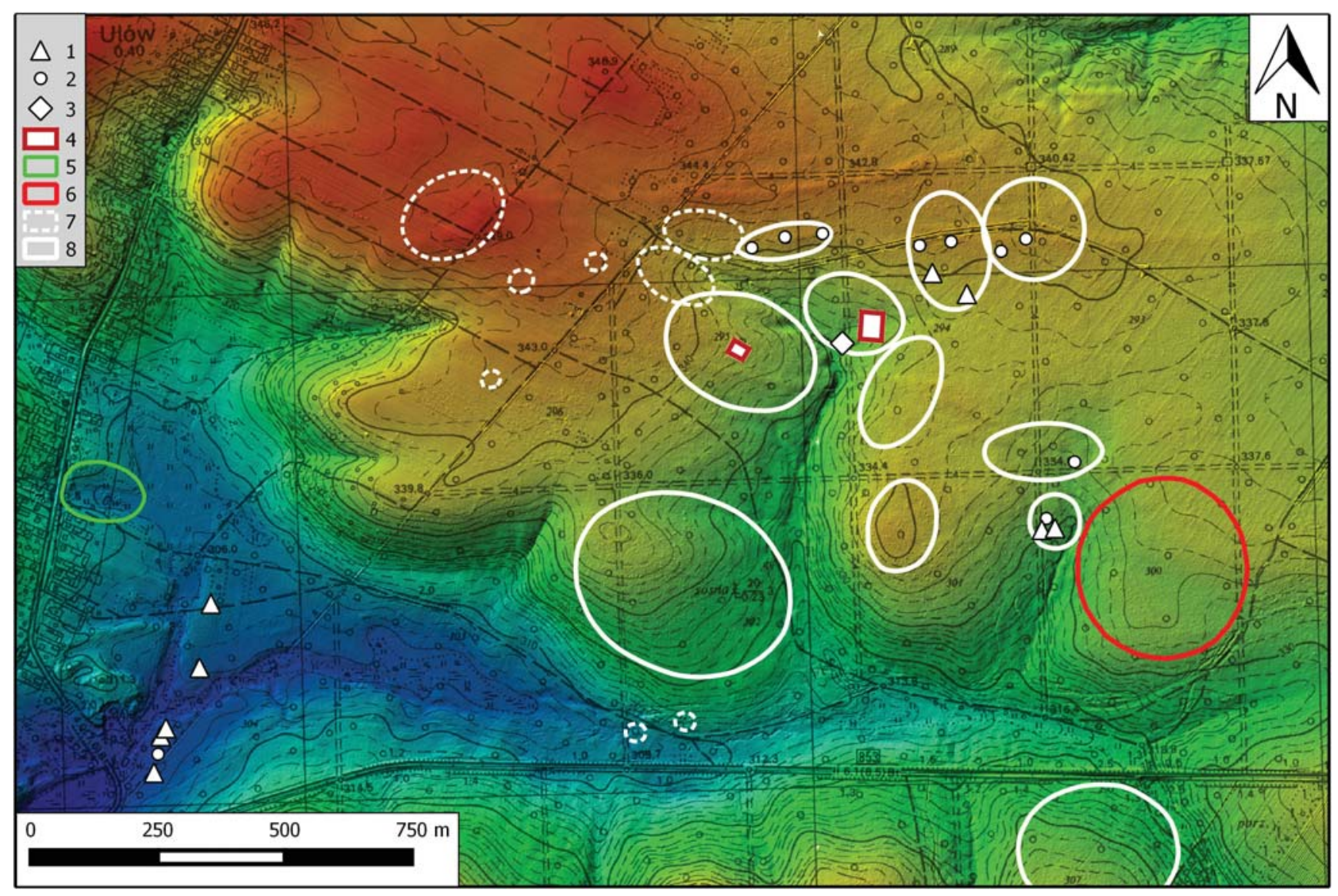

Fig. 4. Distribution of prehistoric and historic human activity sites in the vicinity of Ulów at a background of the DTM hillshade and 1:10 000 topographical map. 1 - prehistoric barrows identified during surface survey and geological drillings; 2 - prehistoric barrows examined during archaeological excavations; 3 - stone wall foundations; 4 - rectangular structures, visible on a ground surface as flat areas surrounded by a ditch and a small ridge; 5 - supposed location of the $17^{\text {th }}$-century glassworks; 6 - archaeological site known from the report of collectors-explorers only; 7 - archaeological sites identified during surface surveys and geophysical research; 8 - ranges of archaeological sites examined during archaeological excavations.

for example resulting from farming (Rejman et al., 2014; Rodzik et al., 2014; Superson et al., 2014).

Widely available topographic map in scale of 1:10 000 was used for a general location. It was used as a working map in field works and as a background map to resulting maps that presented surface formations and topographic features. The map, drawn up in the 1980s based on air photos, has contour lines at every $1.25 \mathrm{~m}$, and does not present any smaller topographic forms (such as barrows), especially in the forested area. The Digital Terrain Model (DTM) developed on the basis of the Airborne Laser Scanning (ALS) was employed in order to provide a more detailed topography. To prepare this, measurement data obtained as a part of the ISOK project (IT system of the National Protection against Extreme Hazards programme) were used. The average point cloud density amounted to four points per $1 \mathrm{~m}^{2}$, with a diameter of a laser beam spot not exceeding $50 \mathrm{~cm}$. The scan angle was $25^{\circ}$ in this case (Kruczyński et al., 2014). For the requirements of the research, the point cloud was reclassified using lasergroung_new tool (implementing the '-nature' option that uses a step size of $5 \mathrm{~m}$ and the '-fine' option, due to steep slopes in the research area) in LAStools software.
DTM of the Triangulated Irregular Network (TIN) type with a resolution of $0.5 \mathrm{~m}$ was generated. Based on this, a number of visualisations were made using RVT 1.1, LiVT, Global Mapper 14 and SAGA GIS software. Hill-shading, multi-hillshading, Sky View Factor (Kokalj et al., 2011), Principal Component Analysis, Local Dominance, Trend Removal, Local Relief Model and Multi-Scale Integral Invariants visualisations were done.

\section{RESULTS}

\section{Geological and soil probing}

Probing revealed an emergence of Cretaceous rocks on elevations of inter-valley prominences and on their hillsides, particularly those of significant inclination (Fig. 6). Generally, weathered rocks as decalcified fragments of silicate-carbonate rocks were found, though in several cases at 332-337 m a.s.l. the argillaceous, carbonate weathered marly silicate-carbonate rock was found. Brown soils, decalcified to a depth of $0.5-0.8 \mathrm{~m}$ developed on weathered silicate-carbonate rocks of the Upper Cretaceous. A 

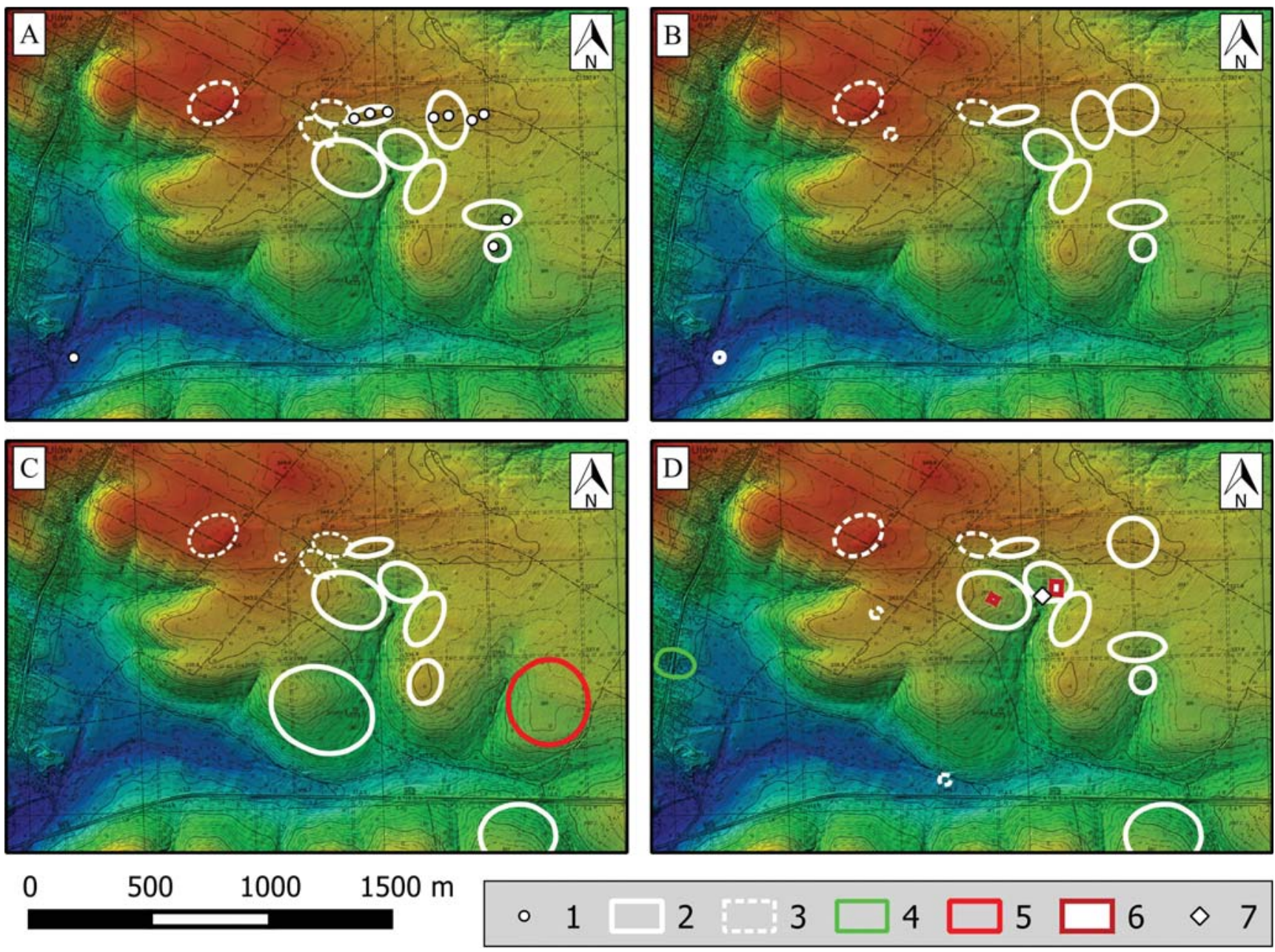

Fig. 5. Distribution of prehistoric and historic settlement sites in the vicinity of Ulów at a background of the DTM hillshade and 1:10 000 topographical map. A - Stone Age, B - Bronze Age; C - Roman Period and early Migration Period, D - Middle Ages and Modern Period; 1 - prehistoric barrows examined during archaeological excavations; 2 - archaeological sites examined during archaeological excavations; 3 - archaeological sites identified during surface surveys and geophysical research; 4 - supposed location of the $17^{\text {th }}$-century glassworks; 5 - archaeological site known only from the report of collectors-explorers; 6 - rectangular structures visible on a ground surface as flat areas surrounded by a ditch and a small ridge; 7 - stone wall foundations.

Carpathian beech wood complex, Fagetum carpaticum, currently predominates there.

As inter-valley prominences descend, the weathered rock is covered with a thickening layer of deluvial sand and silts (Fig. 6). On gentle slopes $\left(<5^{\circ}\right)$ the cover usually starts in the middle part of the slope and it occurs only at the foot on steeper slopes. Rusty and podzolic soils developed on them. The habitat is overgrown with the upland mixed fir forest Abietetum polonicum.

On weathered rocks of the Cretaceous, on hilltops and slope plateaus there are Pleistocene sands several metres thick (Fig. 2). Deluvial, laminated clayey sands and silts form their bottom part, while at the top there are aeolian sands, usually massive and capped with podzol or rusty soils properties. The sands form locally long, narrow and low dune ridges (Fig. 3). Aeolian sands are medium- and fine-grained, and well-sorted. Quartz is dominant, yet feldspars occur too. In places where the sand cover is several metres thick, there are podzolic soils and pine is a dominant tree. Where the sands thickness is less than $2 \mathrm{~m}$ and the rock substratum is near the surface, there is the upland mixed fir forest Abietetum polonicum developed on rusty soils.

In the largest valleys in the southwestern part of the research area, there are fluvial sands of the supra-inundation terrace from the last glaciation (Fig. 2). The forest on the podzolic soils is predominated by a pine. Locally, there are dune sands in short aeolian forms, several metres high.

In the lowest, periodically boggy parts of the valley floors there are sands and clays with organic material, interbedded with peaty silt and peat. In the floors of tributary valleys this Holocene sedimentary series is to $1 \mathrm{~m}$, while in large valleys to 1-2 $\mathrm{m}$ thick. In a small area of these deposits, alder grove and groups of Carex are found on peaty, boggy and post-boggy soils. In boggy areas there are rushes. They were found in a small valley in a village and at intersection of main valleys in the south-western part of the research area. Additionally, they occurred in the centre of the research area in the upper, latitudinal part of a side valley. It is only in this last place that, at the end of the unusually dry summer in 2015, water was found on 


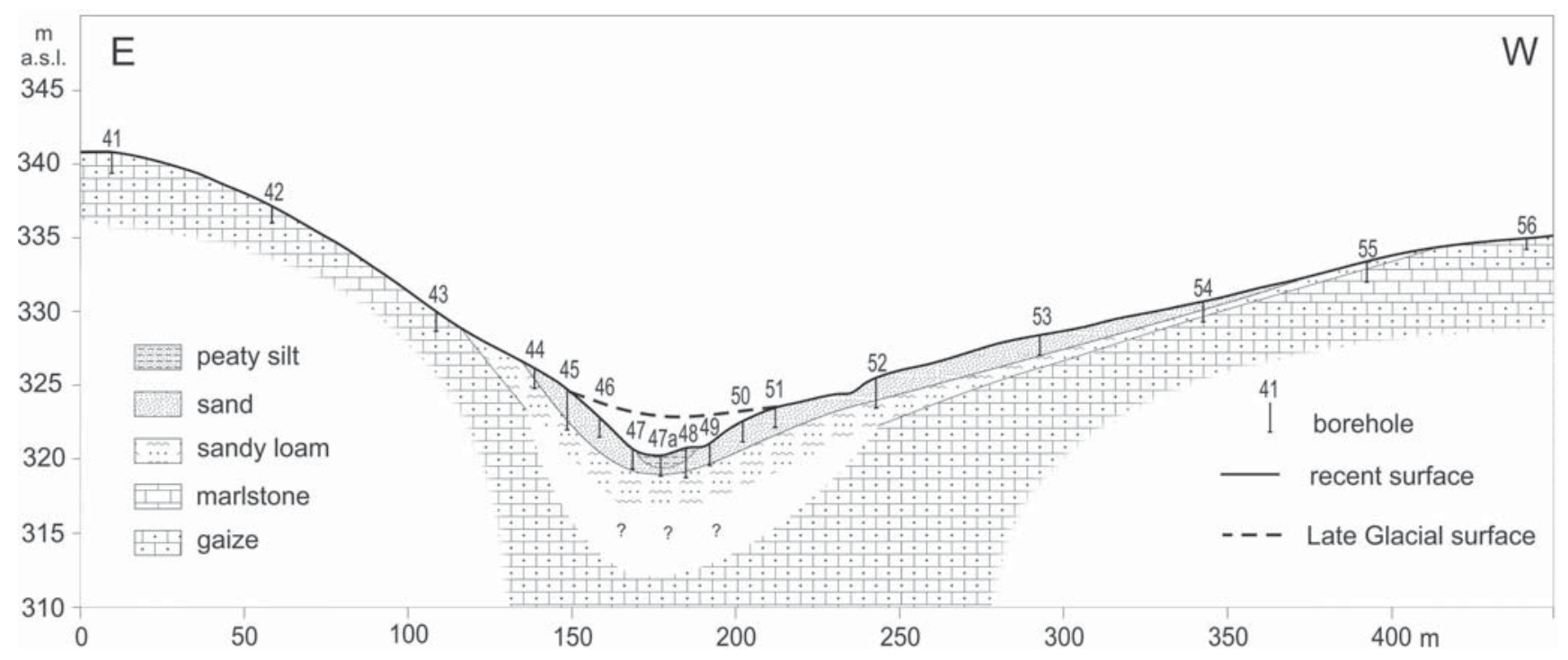

Fig. 6. Geological section across the central small valley (location at Fig. 2).

the surface. Normally, there is a water leak that feeds a fire protection reservoir situated below.

This small valley cuts a floor of a primary valley which is partially filled with sand and silt (Fig. 6). The incisions are several metres deep. The secondary form has a flat floor with a width of about $15 \mathrm{~m}$ and relatively steep slopes (c. $10^{\circ}$ ). In the lower section the incision becomes shallower. At the mouth of a small valley, a sandy floor which is dry here, becomes an alluvial fan composed of sand and silt (Fig. 3). It has uneven surface full of holes, which resembles the terrain after melting ice-layers covered with sand as in the case of a pitted beach (Rodzik and Zagórski, 2009). On the surface of the fan there are also bars and oblong, trough-like channels. On the entire dry surface of the fan (with bars and channels), and on steep slopes of a small valley, there is a well-developed Holocene podzolic or rusty soil.

\section{DTM analysis}

Detailed Digital Terrain Modelling enabled the identification of small topographic forms, invisible on a topographic map. Both natural and anthropogenic forms that were hard to identify or those which could not be identified at all, particularly in the forested areas, were also identified. In this way, several barrows and a system of long, narrow and very low dunes were recognised. These were actually only sedimentary shadows (Fig. 7).

The DTM clearly shows the system of fields of the present-day village of Ulów, which comprises the area to the west of the above-mentioned archaeological sites. They form narrow strips oriented NW-SE and are not ruled by topography. A considerable part of them, located on steep slopes or on the poorest soils, now lies fallow, yet baulks and furrows survived. Direction of ploughing indicated by parallel and oblong microforms is also clearly visible (Fig. 7: 1).

Slightly eroded traces of increased modern farming ac- tivity are visible in the DTM in an area near the archaeological sites where a hilltop is now overgrown with a forest. They are long ribbons oriented SW-NE, with widths from 10-20 to $40 \mathrm{~m}$. In the NE corner of the research area they are dense (Fig. 7: 2). The second cluster of similar, narrow fields, also oriented SW-NE, is on the gentle slope of the small valley with a water leak, on its western side (Fig. 7). Within this group traces of rectangular structure with dimensions of $22 \times 30 \mathrm{~m}$ and with rectangular spaces surrounded by groove and small shafts are located, which was excavated even before receiving the DTM image. Two similar structures were discovered in the inter-valley prominence, where no ploughing traces were noted (Fig. 7). The fourth and the biggest structure with dimensions of $42 \times 52$ $\mathrm{m}$ which has been recognized only by the sample survey is located in a lowering on the eastern side of the valley with a water stream. In its vicinity there are traces of small, narrow fields oriented $\mathrm{W}-\mathrm{E}$, with remains of a rectangular structure cut by ditches (Fig. 7: 3).

Near archaeological sites of prehistoric farming cultures, traces of arable fields were prospected. In several places, on gentle slopes descending to the south, micromorphological DTM captured severely eroded yet still visible traces of prehistoric fields (Fig. 7: 4-5). They are in the form of 'Celtic Fields' (Bradley, 1978; Meylemans et al., 2015), brick-shaped fields with lynchets, yet they have been severely damaged by later road incisions.

In the micromorphological DTM, plaited systems of old roads on a hilltop and on slopes are also visible.

\section{INTERPRETATION AND DISCUSSION}

\section{Relief development}

Valleys that cut the Pliocene planation surface have developed probably during the last several glacial-interglacial 

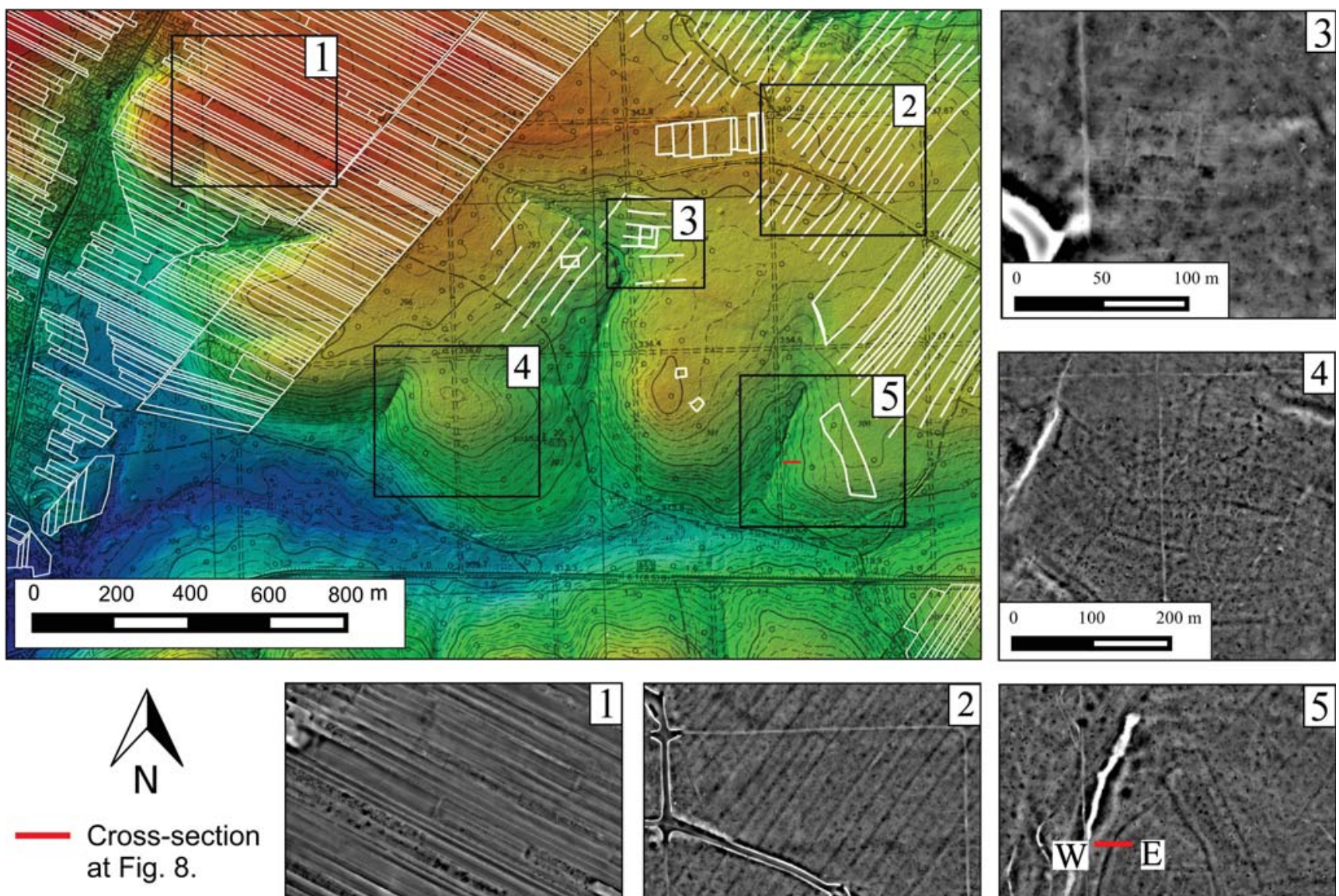

at Fig. 8.
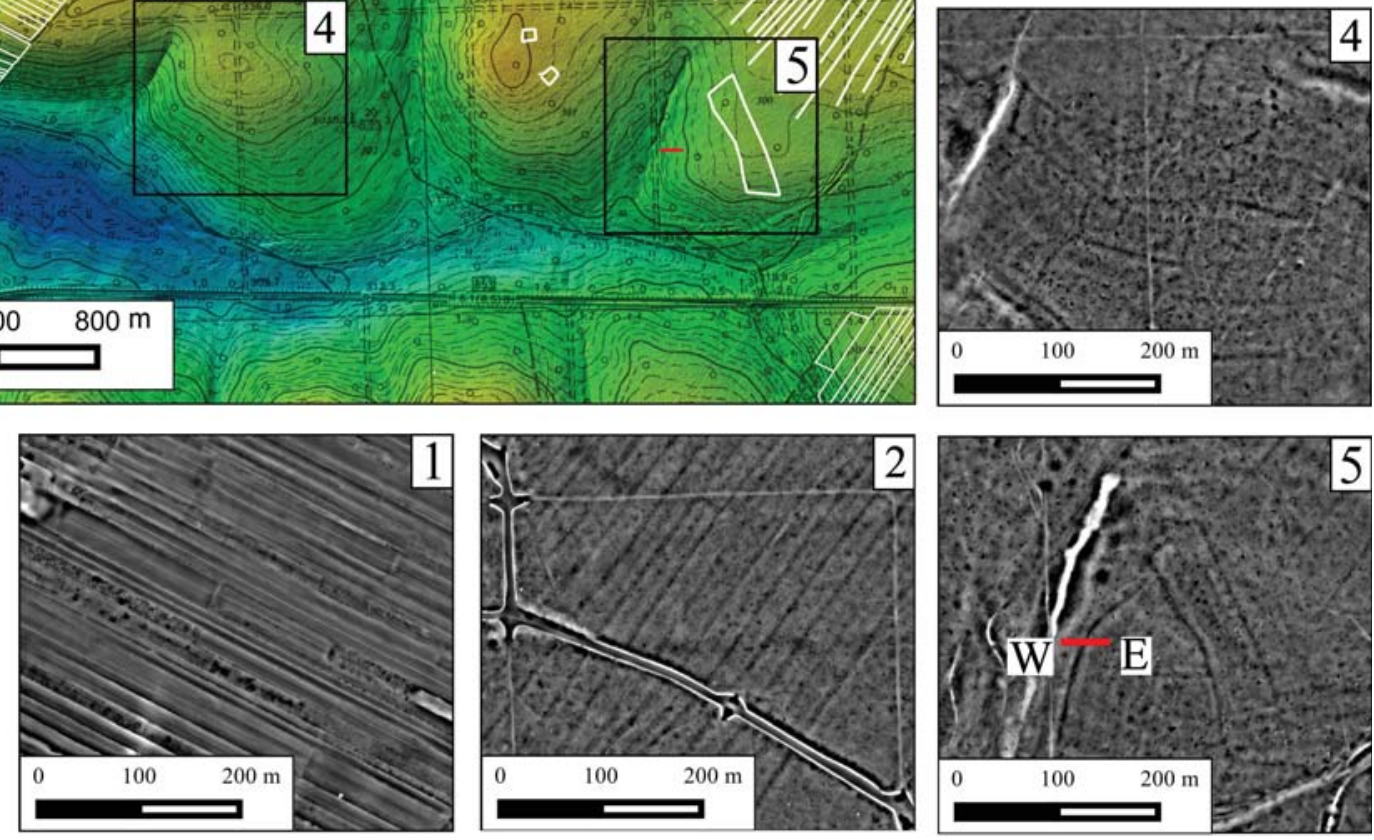

Fig. 7. Prehistoric and historic farming land use in the Ulów area at the background of the DTM hillshade and Local Dominance visualization. 1 - contemporary farming use (state from 2014 based on the ortho-photomap and cadastral data available in the website Geoportal.gov.pl); 2-3 - modern traces of use (boundaries of fields); 4-5 - prehistoric traces of use (boundaries of fields); W-E - cross-section at Fig. 8.

cycles of landform development in the Late Pleistocene. This is indicated by a lack of sediments with northern material as the Scandinavian ice sheets spread over this area about $0.5 \mathrm{mln}$ years ago (Buraczyński et al., 2002). During the Weichselian, sands which were washed away from the slopes were deposited in valley floors. In larger valleys the sands were washed by periodical streams. In smaller valleys, a crosswise transport prevailed. Thus, like a small valley in the centre of the research area, they were filled mostly with sand or sand and silt (Fig. 6). In a severe periglacial climate on the undulating hilltop sand and silt covers were formed, with feldspars that might indicate participation of a glaciofluvial material.

At the termination of the Weichselian these covers underwent aeolisation. However, only low and oblong dune could develop as supplied with a relatively small amount of sand and silt. According to Buraczyński (1993), such dunes developed in the first dune-forming stage at the end of the last glaciation at 15-13.5 kyrs BP. They are arranged in plumed crests (Fig. 3), and their layout refers to a system of strike-slip faults (vide Koprianiuk, 2007). A movement of the block, which was located to the south of dunes, to the east is indicated by the orientation NNW-ESE of the upper reach of a small valley with water, perpendicular to the middle reach and widening of the lower reach of the longitudinal valley at Ulów. Along the fault lines and/or lithological borders of the substratum a crest of long, narrow and very low dunes could develop as a result of sand deposition in more wet places. However, a free water circulation before significant warm spells (Bølling and Allerød) is unlikely. Presumably, the dunes developed at the termination of the last glaciation only, which is indicated by poorly-developed podzolic soils that formed in warmer stages.

At present, the local aquifer on the hilltop might still be on the layer of silicate-carbonate rocks, a location of which (between 330 and $335 \mathrm{~m}$ a.s.1.) corresponds to the level of water leakage in the upper part of the central valley. During the Late Glacial the groundwater table might have been a bit higher as fed by a thawing permafrost. It could stimulate development of dry valleys that formed in a periglacial zone at that time (Maruszczak, 1968). It was probably then that the pleniglacial, sand and silt filling of the central small valley was cut. The outflow of water and the formation of an ice field at the mouth of the valley in 
rapid climatic changes might have resulted from the cut of the aquifer (and snow thawing). Sand and silt material was accumulated on ice and protected from melting in summer. At the latest, this mineral and ice fan melted at the beginning of the Holocene. Holocene podzolic or rusty soil might indicate the pre-Holocene incision and deposition of a fan at its mouth. The soil was well-developed on valley slopes and on the fan. Forest vegetation retained this complex in the Holocene.

The Late Glacial incision drained the relatively vast sandy covers in the floors of larger valleys, at present transformed into a supra-inundation terrace. It enhanced development of dunes, which were shorter but considerably higher than the older forms on a hilltop. Cool phases of the Late Glacial (Older and Younger Dryas) are considered to have been the main dune-forming stages in the Roztocze (Buraczyński, 1993). In places in which the Late Glacial incisions in valley floors reached a local aquifer, it is indicated by deposition of organic deposits (mainly peats). The fact that they were clayey and interbedded with mineral deposits indicates intensive washing in the middle and late Holocene, conditioned by agriculture (Harasimiuk et al., 2008).

In the Holocene anthropogenic forms developed, both intentional (barrows) and created by erosion. Some of well-preserved barrows are to $1.5 \mathrm{~m}$ high, with diameter of 15-22 $\mathrm{m}$. The height of the Majority of barrows are however $0.20-0.50 \mathrm{~m}$ high, with their diameters of $10-12 \mathrm{~m}$. Within three of four barrow concentrations small burial mounds are located next to aforementioned much larger barrows. A distance between individual mounds is from 50 to $80 \mathrm{~m}$. During archaeological excavations of six barrows up to 0.50 $\mathrm{m}$ high, the ploughing traces were not observed. Only in a single case they reached the edge of a mound. Therefore, most probably the small height of most mounds today is not a result of levelling or destruction by farming activity. It can be assumed that their varying diameters and heights point to intentional activity of prehistoric people and indicate conscious arrangement of mounds of various sizes within the cemeteries. This assumption is confirmed by the micro morphological DTM, in which there were no traces of modern fields inside the barrow sites. However, the DTM allowed for a precise location of low mounds, which were very slightly visible, or not visible on a ground surface.

There are also rectangular square structures surrounded by grooves and small shafts, distinct on the micromorphological DTM (Fig. 7: 3). Most likely, they should be connected with the human activities in the modern time, mainly from $17^{\text {th }}$ to early $20^{\text {th }}$ century. This is confirmed by preliminary results of archaeological research, during which th remains of intensive settlement from the $17^{\text {th }}$ century were noted. In addition, the range of small traces of narrow fields oriented west-east in a vicinity of the largest rectangular structures perfectly coincides with fields of the Zamoyski's Estate (the biggest private land estate in Poland), indicated based on measurements in 1875-1906 (Przegon, 2004; collections of the State Archive in Zamość - http://zamosc.ap.gov.pl/p,3,plan-ordynacji). On the same plan, in the NE corner of the study area, the limits of the
Szarowola village are marked, coming into contact with the forest of the Zamoyski's Estate. Small differences between the SW border of these fields visible on the DTM image and the range of fields belonging to the village Szarowola testify probably that before the plan was prepared $\left(17^{\text {th }}-18^{\text {th }}\right.$ centuries?) the areas used for farming were larger than at the end of the $19^{\text {th }}$ century. The cultivated fields were gradually abandoned and overgrown with a forest, and it has a current effect of total forestation of this part of the study area. Indirectly, this process is supported by analysis of topographic maps from 1779-1783 to 1915 (Mapster - http://igrek.amzp.pl/result.php?cmd=pt\&locsys$=1 \&$ uni $=-756791 \&$ box $=0.0001 \&$ hideempty $=$ on). Thus, the DTM analyses document changes in land use and allow to connect them with historical sources.

Anthropogenic erosive forms are mainly road incisions. Systems of old roads on a hilltop are visible in the micromorphological DTM only, whereas they form incisions to $1 \mathrm{~m}$ depth on slopes (Fig. 4). They have been formed by erosion of dirt roads, routes of which were modified after extreme erosion episodes. Ancient forest growing there indicates that these forms developed probably during settlement processes in $17^{\text {th }}-19^{\text {th }}$ centuries at unstable climate of the Little Ice Age. Frequent changes in a course of dirt roads in the southern part of the study area are also visible on topographic maps from $1779-1783$ to 1915 (Mapster - http://igrek.amzp.pl/result.php?cmd=pt\&locsys$=1 \&$ uni $=-756791 \&$ box $=0.0001 \&$ hideempty $=$ on). Similar systems of incisions in the Carpathians are described by Kroczak (2010). In loess areas of the Lublin region, ravine systems developed by erosion of dirt roads (Dotterweich et al., 2012; Superson et al., 2014). Moreover, there are slightly visible traces of terraces of prehistoric fields of undetermined chronology on the slopes (Fig. 8). Traces of a settlement from the Roman and the Early Migration periods recorded there during the archaeological survey and collection of artefacts by searchers using metal detectors may indicate a similar age of prehistoric fields.

\section{Environmental conditions of settlement location}

As a result of excavation works at Ulów it was possible to verify a theory on lack of settlements in the Tomaszów Roztocze. This theory was grounded on identification of the modern natural environment, particularly a hydrography situation in the Roztocze, which is a watershed. At the same time it duplicated a common mistake provided by analyses that neglect environmental and landscape changes between the present day and prehistoric periods (Bintliff, 1992). Despite conducting a search, no traces of prehistoric settlements were discovered in the vicinity of the sudy area, apart from those presented in this paper. Thus, it is vital to indicate reasons why prehistoric people repeatedly established settlements in the immediate vicinity of Ulów, preferring this watershed area. There are artefacts of Corded Ware, Mierzanowice and Trzciniec cultures only that occur also in the valley floor. 


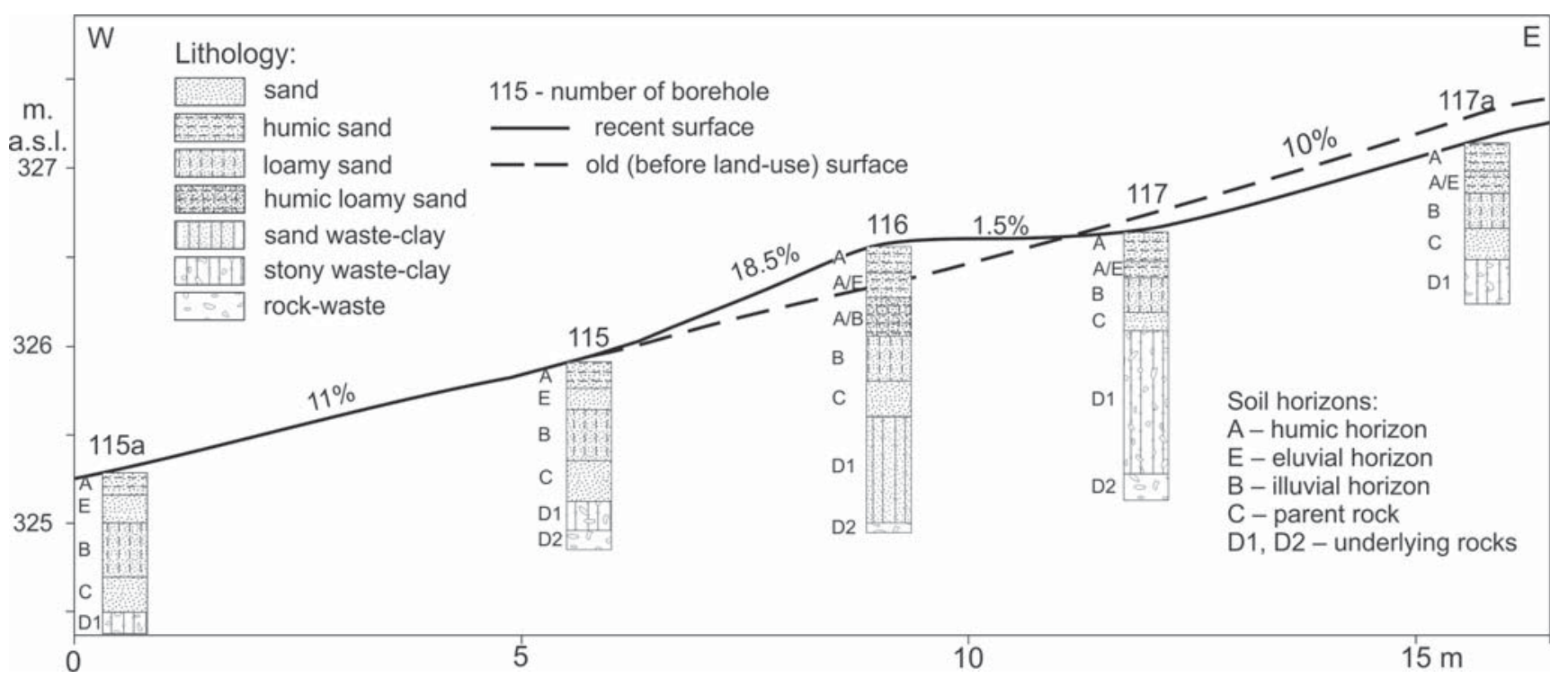

Fig. 8. Pedological-geological section across fossil field-forest border (location at Fig. 7).

It should be stressed that the Tomaszów Roztocze lies in a central part of the Roztocze arch, which connects different landscape areas of the Lublin Upland and the Podolian Upland (Maruszczak and Sirenko, 1989/90; Kondracki, 2009). Areas located to the south-west and north-east are cut by river valleys and they are mostly marshy (Maruszczak, 1998). Thus, the watershed of the Roztocze was a natural bridge running SE-NW and it could have been periodically used for human migration and trade, especially in historical times. Perpendicularly, southwest-northeastern trail connecting the basins of northern Subcarpathian (Sandomierz Basin) and the Volhynian Upland might have run then, the latter being significantly different in terms of landscape.

An important role in spreading of the prehistoric settlements to the centre of the Tomaszów Roztocze could have been also played by major river valleys in this region, together with their small tributaries. Indirectly, this is documented by much denser settlement at the outskirts of the Roztocze, concentrating in the upper basins of the Tanew and Wieprz rivers and to a lesser extent, in the upper basins of the Sołokija and Rata rivers (Machnik, 1959; 1960; 1961; Machnik and Potocki, 1959a, b). Perhaps the prehistoric people penetrating and inhabiting areas in the upper reaches of these rivers gradually approached the vicinity of the Ulów village. Very intense prehistoric settlements were also recorded in the mesoregions neighbouring with the Tomaszów Roztocze in the north-east (Zamość Basin, Hrubieszów Basin, Sokal Ridge and Belz Plain) and the south-west (Sandomierz Basin) (e.g. Machnik, 1966; Kokowski, 1991; Machnik et al., 2009). Most likely, a population of archaeological cultures recorded in the vicinity of Ulów came from these regions, having found here similar environmental conditions as in the original areas. This is best illustrated by arrangement of the Corded Ware Culture sites at Ulów, located in two completely different areas - on a plateau and on a sandy terrace in the valley bottom. The settlements on the plateau can be connected with people who had come from the north-east from the Sokal Perch, where they constructed their barrows in plateaus, similarly as at Ulów (Machnik et al., 2001, 2009; Bagińska and Machnik, 2003). The barrows located in the bottom of the valley may be associated with the people of the Corded Ware Culture arriving from the south from the upper basin of the Tanew River, along the Łosiniec Stream, where burial mounds are located in the valley bottoms as at Ulów (Machnik, 1960, 1966).

Locally, constant presence of water near the watershed in the upper part of the central small valley with a water leak might have been a decisive factor in settling in the vicinity of Ulów by subsequent cultures. Prehistoric settlements, mainly Neolithic, recorded in the northwestern part of the Tomaszów Roztocze and covering the upper basin of the Wieprz River (Balcer et al., 2002) was also largely dependent on the water presence. It concentrated above the flood plain terrace in the valley of this river and near small 'water eyes'. The latter played much greater role in prehistory than at present, which is evidenced by a lack of relationship between location of Neolithic settlements and presence of the largest sources in this area, and their density around small lakes and waterpools (Maruszczak, 2002).

Among other favourable conditions in the vicinity of Ulow there were flatness of the area and soils of average fertility but that could be cultivated easily (vide Maruszczak, 1998). A southern exposure of slopes was also favourable, which is indicated by the fact that arable fields in different epochs were located in similar places. In contrast, settlements in the Lublin region developed intensely in the river valley floors in the early Middle Ages (Hoczyk-Siwkowa, 1999), which might be the reason why they ceased in the hilltop area. Traces of new settlements and farming come from the modern period 
only, which might have been connected with the economic development of this area, connected with establishment of the Zamoyski's Family Fee Tail at the end of the 16th century (Tarnawski, 1935; Kowalski, 2009) and with the foundation of the Ulów village probably in the early 17th century. According to the written sources, in 1565 a sacred spot Uchlowo and the Bear's lake existed in the location in which the village was founded (Chlebowski, 1892, 1902). In this area, numerous fragments of glass slag and glass artefacts were found, pointing to existence of glassworks (Figs. $4 ; 7 \mathrm{D}$ ) in the $17^{\text {th }}-18^{\text {th }}$ century, mentioned in written sources enigmatically as 'glassworks at Ulów' without indicating its location (Wyrobisz, 1968). Presumably, the above-mentioned network of road incisions resulted from the fact that the road leading to it, located on the right slope of the main valley and at its foot, was used.

\section{FINAL REMARKS}

Contrary to the view which resulted from a lack of archaeological investigations, the area of the Tomaszów Roztocze was not totally devoid of settlements and there were areas heavily inhabited in prehistoric times. Excavations, which have been continuing in the vicinity of Ulów for 13 years, indicated a number of cultures settled in this area from the Palaeolithic and Mesolithic to the modern time. Particularly intense in this respect were the Neolithic, the Roman Period and the Migration Period.

The Tomaszów Roztocze is a mesoregion located at the intersection of important, communication trails, which used a system of physiographic units in the regional scale and which could be used in prehistory and in modern times. The trails connected macro- and mesoregions with diverse geological, geomorphological, climatic, hydrological, soil and vegetation conditions.

The location of settlements of subsequent cultures almost in the same place, in an area poorly supplied with water, resulted from particular local conditions, among them soils that could be easily cultivated and favourable microclimatic conditions were significant, yet relatively easy access to water in the flatland was a decisive factor. Presence of water in a form of a leak (small spring) in the upper reach of a small valley cutting the hilltop surface is conditioned by tectonics (strike-slip faults), lithology (impermeable marly layer) and geomorphology (aquifer cut by an erosional-denudation valley). These particularly favourable local conditions contributed to the formation of the settlement enclave surrounded by vast areas devoid of settlements.

Considering the conditions of location of individual cultures, one should take into account not only their environmental preferences, but also locations relative to communication trails in a regional scale and particular conditions in a local scale. One should also take into account changes in geographical environment, which might have occurred as a result of its natural development, but also under influence of human activity.

\section{Acknowledgements}

The work was funded by the National Science Centre (Poland) allocated for the project based on the decision number DEC-2013/09/B/ HS3/03352.

\section{REFERENCES}

Bagińska, J., Niezabitowska, B., 2003. Ulów, Ldkr. Tomaszów Lubelski, Voi. Lubelskie. In: Kokowski, A., Leiber, Ch. (Eds), Die Vandalen. Die Könige - die Eliten - die Krieger - die Handwerker. Ausstellungskatalog, Bevern, 410-411.

Bagińska, J., Niezabitowska, B., 2004. Katalog - Ulów, pow. tomaszowski, woj. lubelskie. In: Andrzejowski, J., Kokowski, A. (Eds), Wandalowie - strażnicy bursztynowego szlaku. Katalog wystawy w Państwowym Muzeum Archeologicznym, Lublin-Warszawa, 284-286 (in Polish).

Bagińska, J., Machnik, J., 2003. Wyniki ratowniczych badań zniszczonego kurhanu na stanowisku $31 \mathrm{w}$ Werszczycy, pow. Tomaszów Lubelski na Grzędzie Sokalskiej. Wyodrębnienie grupy Sokalskiej kultury ceramiki sznurowej. Archeologia Polski Środkowowschodniej 6, 38-57 (in Polish with English summary).

Balcer, B., Machnik, J., Sitek, J., 2002. Z pradziejów Roztocza na Ziemi Zamojskiej. Instytut Archeologii i Etnologii Polskiej Akademii Nauk, Kraków (in Polish with English summary).

Bintliff, J., 1992. Interaction between archaeological sites and geomorphology. Quaternario y Geomorfología 6, 5-20.

Bradley, R., 1978. Prehistoric Field Systems in Britain and North-West Europe - A Review of Some Recent Work. World Archaeology 9 (3), 265-280.

Bronk Ramsey, C., 2009. Bayesian analysis of radiocarbon dates. $R a-$ diocarbon 51 (1), 337-360.

Brzezińska-Wójcik, T., 2013. Morfotektonika w Annopolsko-Lwowskim segmencie pasa wyżynnego w świetle analizy cyfrowego modelu wysokościowego oraz wskaźników morfometrycznych. Wyd. UMCS, Lublin (in Polish with English summary).

Buraczyński, J., 1993. Rozwój procesów eolicznych piętra Wisły na Roztoczu i w Kotlinie Sandomierskiej. Wyd. UMCS, Lublin (in Polish with English summary)

Buraczyński, J., 2002. Regiony Roztocza. In: Buraczyński, J. (Ed.), Roztocze. Środowisko przyrodnicze. Wyd. Lubelskie, Lublin, 75-206 (in Polish).

Buraczyński, J., 2013. Rozwój rzeźby Roztocza. Wyd. Akadem. WSSP, Lublin (in Polish).

Buraczyński, J., Brzezińska-Wójcik, T., Superson, J., 2002. Szczegółowa mapa geologiczna Polski w skali 1:50 000, Tomaszów Lubelski (928) z objaśnieniami. Państwowy Instytut Geologiczny, Warszawa (in Polish).

Buraczyński, J., Chabudziński, Ł., 2014. Geomorphological map of Roztocze 1:50 000; Tomaszów Lubelski. Wydział Nauk o Ziemi i Gospodarki Przestrzennej UMCS, Lublin.

Chlebowski, B. (Ed.), 1892. Słownik geograficzny Królestwa Polskiego i innych krajów słowiańskich XII, Warszawa (in Polish).

Chlebowski, B. (Ed.), 1902. Słownik geograficzny Królestwa Polskiego i innych krajów słowiańskich XV/2, Warszawa (in Polish).

Domańska, L., Kittel, P., Forysiak, J. (Eds), 2009. Środowiskowe uwarunkowania lokalizacji osadnictwa. Środowisko - Człowiek - Cywilizacja 2. Seria wydawnicza Stowarzyszenia Archeologii Środowiskowej, Poznań (in Polish with English summary).

Dotterweich, M., Rodzik, J., Zgłobicki, W., Schmitt, A., Schmidtchen, G., Bork, H.-R., 2012. High resolution gully erosion and sedimentation processes, and land use changes since the Bronze Age and future trajectories in the Kazimierz Dolny area (Nałęczów Plateau, SE-Poland). Catena 95, 50-62. 
Gawrysiak,L.,2004. Województwolubelskie-cieniowanamaparzeźby. Polskie Towarzystwo Geograficzne, Lublin (in Polish).

Gębica, P., 2002a. Charakterystyka geomorfologiczna i geologiczna obszaru w rejonie stanowisk archeologicznych 1-3 w Aleksandrowicach. In: Kadrow, S. (Ed.), Źródła z badań wykopaliskowych na trasie autostrady A4 w Małopolsce. Przyroda i człowiek. Via Archaeologica 1, Kraków, 29-32 (in Polish with English summary).

Gębica, P., 2002b. Charakterystyka geomorfologiczna i geologiczna obszaru w rejonie stanowisk archeologicznych w Kryspinowie. In: Kadrow, S. (Ed.), Źródła z badań wykopaliskowych na trasie autostrady A4 w Małopolsce. Przyroda i człowiek, Via Archaeologica 1, Kraków, 33-36 (in Polish with English summary).

Godłowski, K., 1984. Przemiany osadnicze i kulturowe w południowej i środkowej Polsce w młodszym okresie przedrzymskim i okresie rzymskim. Przegląd Archeologiczny 32, 105-155 (in Polish with German summary).

Harasimiuk, M., Gajek, G., Kołodyńska-Gawrysiak, R., Warowna, J., 2008. Sprawozdanie z badań geologiczno-geomorfologicznych przeprowadzonych $\mathrm{w}$ rejonie stanowisk archeologicznych w Ulowie, pow. tomaszowski. Archeologia Polski Środkowowschodniej X, 95-102 (in Polish with English summary).

Hoczyk-Siwkowa, S., 1999. Małopolska Północno-Wschodnia w VI-X wieku, struktury osadnicze, Lublin (in Polish with English summary).

Jahn, A., 1956. Czwartorzęd Wyżyny Lubelskiej, część środkowa i wschodnia. In: Regionalna geologia Polski 2. Region Lubelski, Wyd. Nauk. PWN, Warszawa. (in Polish)

Jaskanis, D. (Ed.), 1996. Archeologiczne zdjęcie Polski - metoda i doświadczenia. Próba oceny. Warszawa (in Polish with English and German summary).

Kalicki, T., Czerniak, R., 2014. Subatlantyckie zmiany rzeźby Działów Niepołomicko-Bielczańskich na przykładzie wczesnołużyckiego stanowiska Brzezie 26 koło Krakowa. In: Karczewski, M., Smolska, E., Kalicki, T. (Eds), Środowisko przyrodnicze, gospodarka, osadnictwo i kultura symboliczna w V w. p.n.e. - VII w. n.e. w dorzeczach Odry i Wisły. Środowisko-Człowiek-Cywilizacja 3. Seria wydawnicza Stowarzyszenia Archeologii Środowiskowej, Białystok-Warszawa-Kielce, 121-134 (in Polish with English summary).

Karczewski, M., 2011. Archeologia środowiska zachodniobałtyjskiego kręgu kulturowego na pojezierzach, Poznań-Białystok (in Polish).

Karczewski, M., Smolska, E., Kalicki, T. (Eds), 2014. Środowisko przyrodnicze, gospodarka, osadnictwo i kultura symboliczna w V w. p.n.e. - VII w. n.e. w dorzeczach Odry i Wisły. Środowisko Człowiek - Cywilizacja 3. Seria wydawnicza Stowarzyszenia Archeologii Środowiskowej, Białystok-Warszawa-Kielce (in Polish with English summary).

Kaszewski, B.M., 2008. Klimat. In: Uziak, S., Turski, J. (Eds.), Środowisko przyrodnicze Lubelszczyzny. Lubelskie Towarzystwo Naukowe, Lublin, 75-111 (in Polish).

Kittel, P., Skowron, J., 2009. Geomorfologiczne uwarunkowania lokalizacji i rozwoju osadnictwa w rejonie Rawy Mazowieckiej (Polska środkowa) w okresie rzymskim. In: Domańska, L., Kittel, P., Forysiak, J. (Eds), Środowiskowe uwarunkowania lokalizacji osadnictwa. Środowisko - Człowiek - Cywilizacja 2. Seria wydawnicza Stowarzyszenia Archeologii Środowiskowej, Poznań, 147-154 (in Polish with English summary).

Klimek, K., Zygmunt, E., 2007. Sedimentological and geomorphic record of Prehistoric and Early Medieval colonization of the Fore-Sudetic loess plateaus, Southern Poland. In: Makohonienko, M., Makowiecki, D., Czerniawska, J. (Eds), Eurasian Perspectives on Environmental Archaeology. AEA Annual Conference September 12-15, 2007 in Poznań, Poland. Środowisko i kultura 3, Poznań, 81-84.

Kokalj, Ž., Zakšek, K., Oštir, K., 2011. Application of sky-view factor for the visualisation of historic landscape features in lidar-derived relief models. Antiquity 85, 327, 263-273.
Kokowski, A., 1988a. Problematyka kultury wielbarskiej w młodszym okresie rzymskim. In: Gurba, J., Kokowski, A. (Ed.), Kultura wielbarska w młodszym okresie rzymskim (materiały z konferencji) I. Lublin, 15-31 (in Polish with German summary).

Kokowski, A., 1988b. Zagadnienie osadnictwa ludności kultury wielbarskiej na Lubelszczyźnie. In: Gurba, J., Kokowski, A. (Ed.), Kultura wielbarska w młodszym okresie rzymskim (materiały z konferencji) I. Lublin, 241-257 (in Polish with German summary).

Kokowski, A., 1991. Lubelszczyzna w młodszym okresie przedrzymskim i w okresie rzymskim. Lublin (in Polish with German summary).

Kondracki, J., 2009. Geografia regionalna Polski. Wyd. Nauk. PWN, Warszawa (in Polish).

Koprianiuk, M., 2007. Drobne uskoki przesuwcze oraz towarzyszące im struktury niższego rzędu - przykład z kamieniołomu w Lesznej Górnej, jednostka cieszyńska. Przegląd Geologiczny 35, 3, 395404 (in Polish).

Kowalski, M., 2009. Państwo magnackie w strukturach polityczno-administracyjnych Rzeczpospolitej Szlacheckiej na przykładzie Ordynacji Zamojskiej. Przegląd Geograficzny 81, 2, 173-203 (in Polish with English summary).

Kozioł, K., Czerniec, J., Bęgziak, B., Orlikowski, R., 2012. Archeologiczne Zdjęcie Polski jako element infrastruktury informacji przestrzennej. Roczniki Geomatyki X, 4 (54), 133-143 (in Polish with English summary).

Kroczak, R., 2010. Geomorfologiczne i hydrologiczne skutki funkcjonowania dróg polnych na Pogórzu Ciężkowickim. Prace Geograficzne IGiPZ PAN, 225 (in Polish with English summary).

Kruczyński, Z., Stojek, E., Cisło-Lesicka, U., 2014. Zadania GUGiK realizowane w ramach projektu ISOK. In: Podręcznik dla uczestników szkoleń z wykorzystania produktów LiDAR. GUGiK Warszawa, 22-58 (in Polish).

Kunisz, A., 1985. Znaleziska monet rzymskich z Małopolski. Wrocław-Warszawa-Kraków-Gdańsk-Łódź (in Polish).

Machnik, J., 1959. Archeologiczne badania powierzchniowe w południowej Lubelszczyźnie w 1957 r. Sprawozdania Archeologiczne 7, 63-73 (in Polish with English and Russian summary).

Machnik, J., 1960. II sprawozdanie z badań na cmentarzysku kultury ceramiki sznurowej w Łukawicy, pow. Lubaczów. Sprawozdania Archeologiczne 10, 17-22 (in Polish with English and Russian summary).

Machnik, J., 1961. Badania archeologiczne w Roztoczu Lubelskim w 1959 r. Sprawozdania Archeologiczne 12, 89-103 (in Polish with English and Russian summary).

Machnik, J., 1966. Studia nad kulturą ceramiki sznurowej w Małopolsce, Wrocław (in Polish).

Machnik, J., Bagińska, J., Koman, W., 2001. Nowa, synkretyczna grupa kultury ceramiki sznurowej w Polsce środkowo-wschodniej. In: Ginter, B., Drobniewicz, B., Kazior, B., Nowak, M., Połtowicz, M. (Eds), Problemy epoki kamienia na obszarze Starego Świata. Księga Jubileuszowa dedykowana Profesorowi Januszowi K. Kozłowskiemu. Kraków, 389-399 (in Polish with English summary).

Machnik, J., Bagińska, J., Koman, W., 2009. Neolityczne kurhany na Grzędzie Sokalskiej w świetle badań archeologicznych w latach 1988-2006, Kraków (in Polish with English summary).

Machnik, J., Potocki, J., 1959a. Sprawozdanie z badań późnorzymskiego kurhanu w Łukawicy, pow. Lubaczów. Sprawozdania Archeologiczne 5, 49-53 (in Polish with English and Russian summary).

Machnik, J., Potocki, J., 1959b. Badania archeologiczne w widłach Sanu i Tanwi w r. 1956. Sprawozdania Archeologiczne 5, 251-257 (in Polish with English and Russian summary).

Makohonienko, M., Makowiecki, D., Kurnatowska, Z. (Eds), 2007a. Studia interdyscyplinarne nad środowiskiem i kultura w Polsce. Środowisko - Człowiek - Cywilizacja 1. Seria wydawnicza Stowa- 
rzyszenia Archeologii Środowiskowej, Poznań (in Polish with English summary).

Makohonienko, M., Makowiecki, D., Czerniawska, J. (Eds), 2007b. Eurasian Perspectives on Environmental Archaeology. AEA Annual Conference, September 12-15, 2007 in Poznan, Poland. Środowisko i kultura 3, Poznań.

Maruszczak, H., 1968. Procesy denudacyjne w późnym glacjale w świetle badań suchych dolin w Polsce. Folia Quaternaria, 29, 7987 (in Polish with English and Russian summary).

Maruszczak, H., 1972. Wyżyny Lubelsko-Wołyńskie. In: Klimaszewski, M. (Ed.), Geomorfologia Polski 1, PWN, Warszawa, 340-384 (in Polish).

Maruszczak, H., 1998. Geologiczne i geomorfologiczne warunki rozwoju osadnictwa prahistorycznego na Roztoczu. Przegląd Geologiczny 46, 9, 851-856 (in Polish).

Maruszczak, H., 2002. Osobliwości stosunków fizjograficznych Roztocza i ich znaczenie dla działalności człowieka w czasach prahistorycznych i we wczesnym średniowieczu. In: Balcer, B., Machnik, J., Sitek, J. Z pradziejów Roztocza na Ziemi Zamojskiej, Kraków, 207-221 (in Polish with English summary).

Maruszczak, H., Sirenko, I., 1989/1990. Problemy regionalizacji geomorfologicznej wschodniej części wału metakarpackiego. Ann. UMCS, B, 44/45, 37-65 (in Polish with English summary).

Meylemans, E., Creemers, G., De Bie, M., Poesen, J., 2015. Revealing Extensive Protohistoric Field Systems through High Resolution LIDAR Data in the Northern Part of Belgium. Archäologisches Korrespondenzblatt 45, 197-213.

Michalczyk, Z., Wilgat, T., 2008. Wody. In: Uziak, S., Turski, J. (Eds), Środowisko przyrodnicze Lubelszczyzny. Lubelskie Towarzystwo Naukowe, Lublin, 113-209 (in Polish).

Morawska, M., 2014. Rozcięcia erozyjne pogranicza Mazur i Suwalszczyzny na tle sieci osadniczej w epoce żelaza. In: Karczewski, M., Smolska, E., Kalicki, T. (Eds), Środowisko przyrodnicze, gospodarka, osadnictwo i kultura symboliczna w V w. p.n.e. VII w. n.e. w dorzeczach Odry i Wisły. Środowisko - Człowiek - Cywilizacja 3. Seria wydawnicza Stowarzyszenia Archeologii Środowiskowej, Białystok-Warszawa-Kielce, 135-145 (in Polish with English summary).

Mroczek, P., Rodzik, J., 2015. The natural environment surrounding the archaeological site in Klementowice - current situation and retrospective. In: Wiśniewski, T. (Ed.), Klementowice. A Magdalenian site in eastern Poland, Lublin, 235-259.

Niezabitowska, B., 2005. Prace sondażowe i pierwszy sezon badań w Ulowie, stan. 3, pow. Tomaszów Lubelski. Archeologia Polski Środkowowschodniej VII, 111-122 (in Polish with English summary).

Niezabitowska, B., 2007. „Gockie“ osadnictwo z późnego okresu rzymskiego w Ulowie, stan. 3, gmina Tomaszów Lubelski, w świetle znalezisk fibul. In: Fudziński, M., Paner, H. (Eds), Nowe materiały i interpretacje. Stan dyskusji na temat kultury wielbarskiej, Gdańsk, 643-665 (in Polish with German summary).

Niezabitowska-Wiśniewska, B., 2007. Ulów - tajemnica starożytnego Roztocza. In: Kokowski, A. (Ed.), Ulów - tajemnica starożytnego Roztocza; siódma wystawa Instytutu Archeologii Uniwersytetu Marii Curie-Skłodowskiej w Muzeum UMCS, Lublin, 5-38 (in Polish).

Niezabitowska-Wiśniewska, B., 2008. Kompleks osadniczy w Ulowie, powiat tomaszowski - wstępne podsumowanie sześcioletnich badań wykopaliskowych. Archeologia Polski Środkowowschodniej X, 67-93 (in Polish with English summary).

Niezabitowska-Wiśniewska, B., 2009. Archaeology, History and the Heruls. The Lublin Region in Late Roman Period and Migration Period. Barbaricum 8, Warszawa, 195-239.

Niezabitowska-Wiśniewska, B., 2014a. Grot brązowy z Ulowa na Roztoczu Środkowym - próba interpretacji. In: Madyda-Legutko, R., Rodzińska-Nowak, J. (Eds), Honoratissimum assensus genus est arm is laudare. Studia ofiarowane Profesorowi Piotrowi Kaczanowskiemu z okazji siedemdziesiątej rocznicy urodzin, Kraków, 183-193 (in Polish with English and German summary).

Niezabitowska-Wiśniewska, B., 2014b. Miniaturowe naczynka wykonane na kole $\mathrm{z}$ cmentarzysk kultury wielbarskiej w Ulowie na Roztoczu. In: Andrzejowski, J. (Ed.), In medio Poloniae barbaricae. Agnieszka Urbaniak in memoriam. Monumenta Archaeologica Barbarica. Series Gemina III, Warszawa 2014, 163-173 (in Polish with German summary).

Niezabitowska-Wiśniewska, B., 2015. Ulów, stanowisko 7-nowe cmentarzysko kultury wielbarskiej na Roztoczu Środkowym - z badań nad kontaktami kultury wielbarskiej i kultury czerniachowskiej. In: Fudziński, M., Paner, H. (Eds), Kontakty ponadregionalne kultury wielbarskiej. Przemiany kulturowe w okresie wpływów rzymskich na Pomorzu, Gdańsk, 331-362 (in Polish with German summary).

Niezabitowska-Wiśniewska, B., Wiśniewski, T., 2011. Kurhany kultury ceramiki sznurowej na stanowisku $3 \mathrm{w}$ Ulowie, powiat tomaszowski. In: Kowalewska-Marszałek, H., Włodarczak, P. (Eds), Kurhany i obrządek pogrzebowy w IV-II tysiącleciu p.n.e., Kraków, Warszawa, 329-369 (in Polish with English summary).

Niezabitowska-Wiśniewska, B., Wiśniewski, T., in print. A new barrow of the Corded Ware Culture in Middle Roztocze (south-eastern Poland). In: Włodarczak, P. (Ed.), Corded Days in Kraków, Kraków.

Nowaczyk, B., 2008. Changes in natural environment in the vicinity of Osłonki (Kujawy, Central Poland) in the light of geological and geomorphological investigations. In: Nalepka, D. (Ed.), Late Glacial and Holocene Environmental Changes at Osłonki, Central Poland. Folia Quaternaria 78, Kraków, 7-31.

Piotrowski, M., 2004. Wybrane zabytki archeologiczne pochodzące z wielokulturowego st. $22 \mathrm{w}$ Łukawicy, w powiecie lubaczowskim. Rocznik Przemyski XL/2, 127-140 (in Polish with English and German summary).

Piotrowski, M., 2008. Die spätkaiser- und völkerwanderungszeitliche Siedlung von Łukawica, Kr. Lubaczów. Bericht über die Grabungen 2002-2005 und 2007. In: Niezabitowska-Wiśniewska, B., Juściński, M., Łuczkiewicz, P., Sadowski, S. (Eds), The turbulent epoch. New materials from the Late Roman Period and the Migration Period, Monumenta Studia Gothica V, Lublin, 285-294.

Potocki, J., 1960. Kurhany z okresu rzymskiego w Łukawicy w pow. Lubaczów. Materiały Archeologiczne II, 279-290 (in Polish with French summary).

Przegon, W., 2004. Nieznany plan dóbr Ordynacji Zamojskiej w zbiorach Zamojskiego Archiwum. Archiwariusz Zamojski 2004, 7-14 (in Polish).

Reimer, P.J., Bard, E., Bayliss, A., Beck, J.W., Blackwell., PG., Bronk Ramsey, C., Buck, C.E., Cheng, H., Edwards, R.L., Friedrich, M., Grootes, P.M., Guilderson, T.P., Haflidason, H., Hajdas, I., Hatté, C., Heaton, T.J., Hoffmann, D.L., Hogg, A.G., Hughen, K.A., Kaiser, K.F., Kromer, B., Manning, S.W., Niu, M., Reimer, R.W., Richards, D.A., Scott, E.M., Southon, J.R., Staff, R.A., Turney, C., van der Plicht, J., 2013. Intcal13 and Marine13 radiocarbon age calibration curves 0-50,000 years cal BP. Radiocarbon 55(4), 1869-1887.

Rejman, J., Rafalska-Przysucha, A., Rodzik, J., 2014. The Effect of Land Use Change on Transformation of Relief and Modification of Soils in Undulating Loess Area of East Poland. The Scientific World Journal 2014, Article ID 341804, 1-11.

Rodzik, J., Mroczek, P. 2015. Soil probing in the area of the archaeological site in Klementowice as the basis for primary topographic surface reconstruction In: Wiśniewski, T. (Ed.), Klementowice. A Magdalenian site in eastern Poland, Lublin, 265-274.

Rodzik, J., Mroczek, P., Wiśniewski, T., 2014. Pedological analysis as a key for reconstructing primary loess relief - A case study from the Magdalenian site in Klementowice (eastern Poland). Catena $117,50-59$. 
Rodzik, J., Zagórski, P., 2009. Shore ice and its influence on development of shores of the southwestern Spitsbergen. Oceanological \& Hydrobiological Studies 38, suppl. 1, 163-180.

Rogozińska, R., 1963. Sprawozdanie z badań stanowisk kultury trzcinieckiej w Guciowie i Bondyrzu, pow. Zamość, w 1961 roku. Sprawozdania Archeologiczne XV, 84-93 (in Polish with English and Russian summary).

Rogozińska, R., Potocki, J., 1959. Kurhan z okresu rzymskiego w Łukawicy pow. Lubaczów. Wiadomości Archeologiczne XXVI, 335-337 (in Polish).

Sadowski, K., Włodarski, W., 2007. Analiza geomorfologiczna stanowiska archeologicznego Krępnica 8 (7) powiat Bolesławiec. In: Gediga, B. (Ed.), Badania na autostradzie A4, IV. Archeologiczne zeszyty autostradowe VI, Wrocław, 33-46 (in Polish with German summary).

Sadowski, K., Włodarski, W., 2009. Analiza geomorfologiczna otoczenia wielokulturowych stanowisk archeologicznych Polwica 4, Polwica 5, Skrzypnik 8. In: Gediga, B. (Ed.), Badania na autostradzie A4, VI. Osadnictwo neolityczne na wielokulturowych stanowiskach w Polwice i Skrzypniku, pow. Oława. Archeologiczne Zeszyty Autostradowe 8, Wrocław, 131-142 (in Polish with German summary).

Superson, J., Rodzik, J., Reder, J., 2014. Natural and human influence on loess gully catchment evolution: A case study from Lublin Upland, E Poland. Geomorphology 212, 28-40.

Szwarczewki, P., Smolska, E., Mažeika, J., 2014. Zapis pradziejowej i historycznej aktywności gospodarczej w osadach stokowych i fluwialnych na przykładzie okolic Brudzenia Dużego (północne Mazowsze). In: Karczewski, M., Smolska, E., Kalicki, T. (Eds), Środowisko przyrodnicze, gospodarka, osadnictwo i kultura symboliczna w V w. p.n.e. - VII w. n.e. w dorzeczach Odry i Wisły Środowisko - Człowiek - Cywilizacja 3. Seria wydawnicza Stowarzyszenia Archeologii Środowiskowej, Białystok-WarszawaKielce, 161-172 (in Polish with English summary).

Tarnawski, A., 1935. Działalność gospodarcza Jana Zamoyskiego kanclerza i hetmana W.Kor. (1572-1605), Lwów (in Polish).
Twardy, J., 2014. Przemiany rzeźby centralnej Polski w okresie V w. p.n.e. - VII w. n.e. w warunkach zmian klimatu i narastającej antropopresji. In: Karczewski, M., Smolska, E., Kalicki, T. (Eds), Środowisko przyrodnicze, gospodarka, osadnictwo i kultura symboliczna w V w. p.n.e. - VII w. n.e. w dorzeczach Odry i Wisły. Środowisko - Człowiek - Cywilizacja 3. Seria wydawnicza Stowarzyszenia Archeologii Środowiskowej, Białystok-WarszawaKielce, 147-159 (in Polish with English summary).

Welc, F., Woronko, B. (Eds), 2011. Geoarchaeology in Poland. Archaeologia Polona 49.

Wiśniewski, T., 2007. Zanim przyszli Germanie. In: Niezabitowska-Wiśniewska, B., Ulów - tajemnicastarożytnego Roztocza. Siódma wystawa Instytutu Archeologii Uniwersytetu Marii Curie-Skłodowskiej w Muzeum UMCS. Katalog wystawy, Lublin, 39-48 (in Polish).

Wyrobisz, A., 1968. Szkło w Polsce od XIV do XVII w., WrocławWarszawa-Kraków (in Polish with French summary).

Wyrwicka, K., 1977a. Obecny stan rozpoznania i perspektywy rozwoju bazy kredowych surowców węglanowych na Wyżynie Lubelskiej. Przegląd Geologiczny 25, 12, 643-650 (in Polish).

Wyrwicka, K., 1977b. Wykształcenie litologiczne węglanowych surowców skalnych mastrychtu lubelskiego. Biuletyn Państwowego Instytutu Geologicznego 299, 5-98 (in Polish with Russian and English summary).

Zgłobicki, W., 2008. Geochemiczny zapis działalności człowieka w osadach stokowych i rzecznych, Lublin (in Polish with English summary).

Zgłobicki, W., Juściński, M., Niezabitowska-Wiśniewska, B., Piotrowski, M., Kozieł, M., 2014. Wpływ ukształtowania terenu i procesów geomorfologicznych na geochemię gleb stanowisk archeologicznych. In: Karczewski, M., Smolska, E., Kalicki, T. (Eds), Środowisko przyrodnicze, gospodarka, osadnictwo i kultura symboliczna w V w. p.n.e. - VII w. n.e. w dorzeczach Odry i Wisły. Środowisko - Człowiek - Cywilizacja 3. Seria wydawnicza Stowarzyszenia Archeologii Środowiskowej, Białystok-Warszawa-Kielce, 173-180 (in Polish with English summary). 